\title{
Corticosteroid use and bone mineral accretion in children with asthma: Effect modification by vitamin D
}

\section{Citation}

Tse, Sze Man, H. William Kelly, Augusto A. Litonjua, Mark L. Van Natta, Scott T. Weiss, and Kelan G. Tantisira. 2012. Corticosteroid use and bone mineral accretion in children with asthma: Effect modification by vitamin D. Journal of Allergy and Clinical Immunology 130, no. 1: 53-60.e4. doi:10.1016/j.jaci.2012.04.005.

\section{Published Version}

doi:10.1016/j.jaci.2012.04.005

\section{Permanent link}

http://nrs.harvard.edu/urn-3:HUL.InstRepos:27003769

\section{Terms of Use}

This article was downloaded from Harvard University's DASH repository, and is made available under the terms and conditions applicable to Other Posted Material, as set forth at http:// nrs.harvard.edu/urn-3:HUL.InstRepos:dash.current.terms-of-use\#LAA

\section{Share Your Story}

The Harvard community has made this article openly available.

Please share how this access benefits you. Submit a story.

Accessibility 


\title{
Corticosteroid use and bone mineral accretion in children with asthma: effect modification by vitamin D
}

\author{
Sze Man Tse, MDCMa ${ }^{\mathrm{a}}$ H. William Kelly, PharmD ${ }^{\mathrm{b}}$, Augusto Litonjua, MD, MPH ${ }^{\mathrm{a}}$, Mark L. \\ Van Natta, MHS ${ }^{c}$, Scott T. Weiss, MD, MS ${ }^{a}$, and Kelan Tantisira, MD, MPH ${ }^{a}$ on behalf of the \\ CAMP Research Group
}

aChanning Laboratory, Brigham and Women's Hospital and Harvard Medical School, Boston, Massachusetts ${ }^{b}$ Department of Pediatrics, University of New Mexico Health Sciences Center, Albuquerque, New Mexico ${ }^{C} J o h n s$ Hopkins Center for Clinical Trials, Baltimore, Maryland

\begin{abstract}
Background-The adverse effects of corticosteroids on bone mineral accretion (BMA) have been well documented. Vitamin D insufficiency, a prevalent condition in the pediatric population, has also been associated with decreased bone mineral density (BMD).
\end{abstract}

Objective-To determine whether children with asthma who have lower vitamin D levels are more susceptible to the negative effects of corticosteroids on BMD over time.

Methods-Children aged 5-12 years with mild-to-moderate asthma who participated in the Childhood Asthma Management Program were followed for a mean of 4.3 years. Total doses of inhaled and oral corticosteroids (OCS) were recorded, serum 25-hydroxyvitamin D3 levels were measured at the beginning of the trial and serial DEXA scans of the lumbar spine were performed. Annual BMA rates were defined as: [(BMD at 4 years follow-up - BMD at baseline)/4 years].

Results-BMA was calculated for 780 subjects. In boys, baseline vitamin D levels significantly modified the relationship between OCS and BMA (vitamin D x OCS interaction, $\mathrm{p}=0.023$ ). Stratification by vitamin D levels showed a decrease in BMA with increased use of OCS in vitamin $\mathrm{D}$ insufficient boys only ( $\mathrm{p}<0.001$ ). Compared to vitamin $\mathrm{D}$ sufficient boys, vitamin $\mathrm{D}$ insufficient boys exposed to more than 2 courses of oral corticosteroids per year had twice the decrease in BMA rate (relative to boys who were OCS-unexposed).

Conclusions-Vitamin D levels significantly modified the effect of oral corticosteroids on bone mineral accretion in boys. Further research is needed to examine whether vitamin D supplementation in children with poorly controlled asthma may confer benefits to bone health.

\section{Keywords}

Asthma; vitamin D; bone mineral density; corticosteroids

\footnotetext{
(C) 2012 American Academy of Allergy, Asthma and Immunology. Published by Mosby, Inc. All rights reserved. Address correspondence to Sze Man Tse, MDCM, at the Channing Laboratory, 181 Longwood Avenue, Boston, MA 02115, USA; Tel: (617) 525-2126; Fax: (617) 525-0958; reszt@channing.harvard.edu.

The authors have no financial disclosures and conflict of interest to declare.

This paper is subject to the NIH Public Access Policy (http://publicaccess.nih.gov)

Publisher's Disclaimer: This is a PDF file of an unedited manuscript that has been accepted for publication. As a service to our customers we are providing this early version of the manuscript. The manuscript will undergo copyediting, typesetting, and review of the resulting proof before it is published in its final citable form. Please note that during the production process errors may be discovered which could affect the content, and all legal disclaimers that apply to the journal pertain.
} 


\section{Introduction}

Osteoporosis and osteopenia are diseases characterized by low bone mass, with osteopenia affecting 34.5 million individuals above the age of 50 years in the United States ${ }^{1}$. The consequential fractures are major causes of morbidity and high healthcare expenditures. Bone mineral mass is a key determinant of fracture risk and while the accretion of bone mass starts in the fetus, the skeletal system continues its development and maturation throughout childhood and adolescence. Since most of the skeletal mass is achieved before the end of the second decade of life ${ }^{2}$, factors affecting bone mineral accretion (BMA), defined as the change in bone mineral density (BMD) over time, during this critical period may also affect bone mass and fracture risk later in life.

Vitamin D plays an essential role in bone metabolism. Its active form, 1,25dihydroxyvitamin $\mathrm{D}$, enhances bone mineralization by increasing intestinal calcium and phosphorus absorption and inducing osteoclast maturation ${ }^{3}$. An estimated $55 \%$ of the US population has a serum 25-hydroxyvitamin D level below $30 \mathrm{ng} / \mathrm{ml}$, the usual cutoff for vitamin $\mathrm{D}$ insufficiency ${ }^{4}$. In the pediatric population, the association between severe vitamin $\mathrm{D}$ deficiency and rickets is well established. In addition, vitamin D insufficiency has been associated with low bone mass and bone mineral density ${ }^{5}$.

The adverse effects of corticosteroids on bone health are also well recognized. In adults, corticosteroid use is associated with decreased bone mineral density ${ }^{6}$. In children, this causal relationship is more complex and additional factors need to be taken into account, such as sex, age, height, pubertal status and skeletal maturity ${ }^{7}$. In asthma, a condition affecting about $12.9 \%$ of the US population ${ }^{8}$, the risk of adverse side effects from corticosteroid usage is of genuine concern, since inhaled corticosteroids (ICSs) are the most commonly prescribed medications for the long term control of asthma and oral corticosteroids are the therapy of choice for inflammatory control of acute asthma exacerbations ${ }^{9}$. We previously reported that oral corticosteroid (OCS) usage in children with asthma was associated with significant decrements in bone mineral accretion rates ${ }^{10}$; these effects were most dramatic in boys with high cumulative oral corticosteroid intake.

Given that both vitamin D insufficiency and corticosteroid usage may each have adverse effects on BMD, we hypothesized that children with lower vitamin D levels may be more susceptible to the negative effects of corticosteroids on BMD over time. To test this hypothesis, we analyzed the joint effects of vitamin D levels and corticosteroid dosing on BMA on subjects participating in the Childhood Asthma Management Program (CAMP).

\section{Methods}

\section{Study population}

The demographics of the subjects enrolled in CAMP and the study design have been described previously ${ }^{11}$. Briefly, 1,041 children with mild-to-moderate asthma aged 5 to 12 years were randomized to budesonide, nedocromil or placebo. This was a multi-center trial designed to evaluate the long-term effects of these treatments on lung growth. Follow-up visits occurred at two and four months after randomization and every four months thereafter. The children's parents or guardians provided informed consent and the study was approved by the local institutional review board. Subjects were followed for a mean of 4.3 years.

\section{Serum 25-hydroxyvitamin D3}

Serum levels of 25-hydroxyvitamin D3 (hereafter referred to as vitamin D) were measured at the beginning of the study for 1,024 patients (98\% of enrolled subjects) using a 
radioimmunoassay method ${ }^{12,13}$. We categorized this measurement into insufficient ( $\$ 30 \mathrm{ng}$ / $\mathrm{mL}$ ) and sufficient $\left(>30 \mathrm{ng} / \mathrm{mL}\right.$ ) based on previous recommendations ${ }^{14}$ and consistent with our prior publications in this area ${ }^{12,15}$.

\section{Bone mineral density}

BMD measurements $\left(\mathrm{g} / \mathrm{cm}^{2}\right)$ of the lumbar spine (L1-L4) were performed yearly during the study period and were described previously in detail ${ }^{10}$. Measurements were taken by dual energy x-ray absorptiometry (DEXA) using the Hologic (Waltham, MA) QDR-1500 at 6 centers or the Lunar (Madison, WI) DPX at 2 centers at the beginning of the study. Hologic DEXA machines were further divided by the use of pencil beam or fan beam measurements. In order to compare BMD measurements, Lunar measures were converted to Hologic values using the following equation: Hologic $\mathrm{BMD}=0.885 \times$ Lunar BMD $^{16}$. Furthermore, the following adjustment was made to account for deviations between pencil and fan beam measurements: fan-beam BMD = pencil-beam BMD + 0.549 if height $\geq 1.40 \mathrm{~m}$. Subjects from one study center were excluded because of the inability to standardize the initial DEXA values. Due to the lack of adequate BMD references for our population, yearly bone mineral accretion (BMA, $\mathrm{g} / \mathrm{cm}^{2} /$ year) over the duration of the trial was chosen to be the primary outcome, consistent with our previous work ${ }^{10}$. BMA is a measure closely related to BMD and represents the average gain of BMD over time, hereby defined as [(BMD at 4 years follow-up - BMD at baseline)/4 years]. A 4-year follow-up was chosen because this approximated the end of the trial and the number of patients with a BMD measure was maximized at that time point. BMD z-scores were calculated using CAMP internal references ${ }^{10}$.

\section{Corticosteroid dosages}

During the study period, patients were randomized to inhaled budesonide $200 \mu \mathrm{g}$ twice daily, nedocromil $8 \mathrm{mg}$ twice daily or placebo twice daily ${ }^{11}$. The use of beclomethasone dipropionate or other ICS was also allowed if the control of asthma was inadequate. For asthma exacerbations, short courses of oral prednisone were prescribed per protocol. Each burst consisted of $2 \mathrm{mg} / \mathrm{kg}$ per day up to $60 \mathrm{mg}$ of prednisone for 2 days followed by $1 \mathrm{mg}$ / $\mathrm{kg}$ per day up to $30 \mathrm{mg}$ for 2 days. If there was insufficient improvement, an option to continue dosing was available. Dosage, duration and frequency of ICS and oral prednisone bursts were recorded at each follow-up visit.

For analysis purposes, three measures of corticosteroid exposure were examined: exposure to budesonide vs. nedocromil or placebo (intention-to-treat analysis), cumulative ICS and cumulative OCS. The cumulative ICS dose was divided into 3 categories: $0,>0-437$, and $\geq 438 \mathrm{mg}$. The arbitrary cut point of $438 \mathrm{mg}$ represents 3 years of full dosage of budesonide $(400 \mu \mathrm{g} / \mathrm{day})$ out of the 4 years of the study, consistent with our prior analysis ${ }^{10}$. The cumulative oral corticosteroid (OCS) dose was divided into 4 categories: $0,>0-4,>4-8, \geq 9$ bursts of $180 \mathrm{mg}(60 / 60 / 30 / 30 \mathrm{mg} /$ day as one burst for patients weighing at least $30 \mathrm{~kg})$. We chose these cutoffs because over the follow-up period, this is equivalent to $0, \unlhd$, and $>1$ to 2 and $>2$ courses of OCS per year, a clinically meaningful measure of OCS use that is easy to interpret.

\section{Statistical analysis}

A descriptive analysis of baseline characteristics and univariate predictors was performed. When applicable, a chi-square test was used to compare proportions, a t-test to compare means and Wilcoxon rand sum test to compare medians. A Cochran-Armitage trend test was performed to compare Tanner stages between groups. Variables that were significantly associated with the outcome and one of the exposures at a $p<0.10$ were included in the multivariable model. Multiple linear regression models were constructed and the effect of 
different steroid exposures on BMA was tested for effect modification by vitamin D levels via incorporation of a formal interaction term and confirmed through stratified analyses. For each steroid exposure, analyses were stratified by gender and vitamin D levels ( $30 \mathrm{ng} / \mathrm{mL}$ vs. $>30 \mathrm{ng} / \mathrm{mL}$ ). Using a total sample size of 780 , there is an $80 \%$ power to detect a difference in BMA of $0.005 \mathrm{~g} / \mathrm{cm}^{2} /$ year between the vitamin D insufficient and sufficient groups, at a significance level of 0.05 . $\mathrm{P}$ values are 2-sided. All analyses were performed using R, version 2.12.1 (www.r-project.org).

\section{Results \\ Patient demographics}

From the 7 eligible study centers, a total of 780 subjects had a baseline vitamin D level and a BMD measurement at baseline and at 4 years follow-up. The subjects lost to follow-up had a lower BMI and higher vitamin D level compared to the study participants, but other demographics did not differ significantly, including the percent of randomization to budesonide (Table E1 in Online Repository). The median vitamin D level was $34.3 \mathrm{ng} / \mathrm{mL}$ (IQR 26.9, 45.6) and the median BMA was $0.041 \mathrm{~g} / \mathrm{cm}^{2} /$ year (IQR 0.026, 0066). Baseline characteristics of the study population by vitamin $\mathrm{D}$ status are presented in Table I. The majority of subjects were at Tanner stage 1 (breast stage for girls and genital stage for boys) at the beginning of the trial. While there is a clear progression through the pubertal stages throughout the trial, there was a predominance of females in later pubertal stages (Tanner 3, 4 , and 5) at 4 years follow-up ( $\mathrm{p}=0.0001)$.

\section{Effect of corticosteroids on BMA}

There were 231 (29.6\%) subjects randomized to the budesonide treatment arm and an additional 147 subjects from the other 2 treatment arms were exposed to any ICS, with a median cumulative ICS dose of $560 \mathrm{mg}$ (IQR 295, 585). The majority of subjects received $\geq 438 \mathrm{mg}(\mathrm{n}=235)$ of which $92.8 \%$ were from the budesonide randomized arm. The majority of the subjects received OCSs during the trial, with a median cumulative OCS dose of 540 $\mathrm{mg}$ (IQR 205, 1064). Among those who received $\geq 5$ bursts of OCS ( $\geq 1$ course per year), the median number of bursts was 8.0. Univariate regression analysis showed that age, sex, height, BMI, Tanner stage, race, and baseline BMD to be significantly associated with BMA and one of the exposures. Therefore, all multivariable regression analyses were adjusted for these variables. Overall, randomization to budesonide $(\mathrm{p}=0.77)$ and cumulative ICS use $(\mathrm{p}=0.09)$ had no significant effect on BMA, but there was a dose-dependent decrease in BMA among individuals taking OCSs $(\mathrm{p}=0.008)$, consistent with our previous results over a longer follow-up period (median 7 years) ${ }^{10}$.

\section{Effect of corticosteroids on BMA by vitamin D status}

Table II shows the change in annual BMA with different corticosteroid exposures, stratified by vitamin D level and sex. Vitamin D status at baseline did not modify the relationship between CAMP randomization to budesonide and BMA using intention-to-treat analysis (interaction between budesonide and vitamin $\mathrm{D}$ level, $\mathrm{p}=0.53$ for boys and $\mathrm{p}=0.79$ for girls). In vitamin D sufficient boys, a significant decrease in BMA was noted with increasing ICS use ( $\mathrm{p}=0.007)$. However, there was no significant effect modification by vitamin $\mathrm{D}$ on the relationship between cumulative ICS and BMA ( $\mathrm{p}=0.48$ for boys and $\mathrm{p}=0.90$ for girls). A significant interaction term between vitamin $\mathrm{D}$ and OCS use for boys $(\mathrm{p}=0.02)$ supports an effect modification by vitamin D on the effect of OCS on BMA. In boys, there was a significant decrease in BMA with increasing use of OCSs in the vitamin D insufficient group only ( $\mathrm{p}<0.001 ; 95 \% \mathrm{CI}-0.008,-0.002)$. Specifically, each increase in category of OCS exposure was associated with a significant decrease in BMA $\left(0.005 \mathrm{~g} / \mathrm{cm}^{2} / \mathrm{year}\right)$. Of the vitamin D insufficient CAMP boys taking more than two courses of OCS per year and 
compared to those taking no OCS, the difference in medians was $-0.027 \mathrm{~g} / \mathrm{cm}^{2} /$ year for BMA and -0.819 for BMD z-score, compared to $-0.014 \mathrm{~g} / \mathrm{cm}^{2} /$ year and -0.122 respectively for vitamin D sufficient boys. Figure 1 shows the difference in BMA between OCS-exposed and OCS-unexposed boys, with twice the difference in BMA associated with moderate to high OCS usage noted in the vitamin D insufficient group compared to the vitamin D sufficient group. An OCS dose-dependent decrease in BMD z-score was also observed in vitamin $\mathrm{D}$ insufficient boys ( $<<0.001 ; 95 \% \mathrm{CI}-0.279,-0.077$; interaction term $\mathrm{p}=0.04$, Table III). In females, there was no significant decrease in BMA with increasing OCS intake and no effect modification by vitamin D. Interestingly, among those not exposed to steroids, BMA was higher in the vitamin D insufficient group (Table II). Compared to their vitamin D sufficient counterparts, these subjects were overall younger, had lower BMI percentiles, were in lower pubertal stages and consisted of more white subjects (Table E2-E4 in Online Repository). After adjustment for covariates, vitamin D insufficiency was not associated with BMA ( $\mathrm{p}=0.65, \mathrm{p}=0.38, \mathrm{p}=0.06$ for non-exposed to budesonide, ICS and OCS, respectively).

\section{Discussion}

In this evaluation of the combined effects of vitamin D and corticosteroid use on BMA and BMD in children with asthma, we found a dose-dependent effect of OCS use on BMA in boys that was significantly modified by serum $25(\mathrm{OH})_{2} \mathrm{D}$ levels. Specifically, boys with lower vitamin D levels ( $\$ 30 \mathrm{ng} / \mathrm{mL}$ ) had a doubling of the decrease in BMA following exposure to a moderate to high number of OCS treatment courses for asthma exacerbations (Figure 1). This effect was most notable in subjects taking the equivalent to $>2$ courses of OCS per year, a relatively common occurrence in clinical practice. A longitudinal observational study in the UK reported that about $12 \%$ of children aged 5 to 11 years with diagnosed asthma received one or more courses of OCS per year ${ }^{17}$. This, combined with the high prevalence of vitamin D insufficiency ${ }^{4}$, suggests that many children with asthma are particularly vulnerable to decrements in bone density. There was no evidence of an effect of cumulative ICS or budesonide as per randomization on BMA and no evidence of effect modification by vitamin $\mathrm{D}$. This is consistent with previous findings that ICS use has no adverse effects on BMD in children ${ }^{10,18-20}$.

Our study adds to several existing studies that have cited an association of OCS usage to decreased BMD or BMA ${ }^{10,21,22}$, by noting a specific subgroup, vitamin D insufficiency, as being at greatest risk for this adverse outcome. We observed that among both boys and girls who were not exposed to OCS, BMA and BMD z-score were higher in those who were vitamin D insufficient. However, the association between vitamin D insufficiency and increased BMA was not significant after adjustment for baseline BMD, sex, BMI percentile and Tanner stage, stressing the importance of these risk factors when examining BMA. While the clinical significance of a decreased BMA and changes in BMD z-score as related to future fractures are not well established in children given the lack of prospective longitudinal studies, in adults, a 1 standard deviation decreased in spine BMD is associated with a 2-fold increase in fracture risk ${ }^{23}$. Additionally, Van Staa et al reported a 1.3 times increase in odds of fracture in children aged 4-17 years taking $\geq 4$ courses of OCS over a mean follow-up of 2.7 years ${ }^{24}$. Further research is needed to determine whether OCS bursts combined with vitamin D insufficiency during childhood and adolescence has a cumulative effect on peak bone mass and long-term fracture risks.

There are several potential biologic reasons to support the interaction of corticosteroids with vitamin $\mathrm{D}$ on bone health. Corticosteroids reduce bone mineral accretion and contribute to corticosteroid-induced osteoporosis by impairing the function and differentiation of osteoblasts and by increasing osteoclasts activity. Furthermore, they induce apoptosis of 
osteoblasts while having an anti-apoptotic effect on osteoclasts, resulting in accelerated bone resorption $^{25}$. At the intestinal level, corticosteroids inhibit vitamin D-dependent intestinal calcium absorption and decreased expression of specific duodenal calcium transporters ${ }^{6,26}$. Rickets and osteomalacia are well-documented adverse effects of severe vitamin D deficiency. Vitamin D insufficiency has been associated with compensatory increase in parathyroid hormone (PTH) secretion ${ }^{27}$, which can lead to bone resorption and reduced bone mineral density ${ }^{28}$. Differentiation and prevention of osteoclast apoptosis is mediated by the binding of receptor activator of NF- $\kappa$ B ligand (RANKL) to its receptor RANK, which can be neutralized by RANKL's inhibitor osteoprotegerin (OPG). Both corticosteroids and vitamin D insufficiency contribute to bone loss by increasing the RANKL/OPG ratio ${ }^{29}$.

In this study, the adverse dosage-dependent effect of OCS on BMA and the effect modification by serum vitamin D levels were significant only in boys, despite adjustment for Tanner staging. While there is an established sexual dimorphism in cortical bone density development, the relative importance of sex hormones on trabecular bone density, which is measured by DEXA, is being elucidated. Murine models suggest that androgens are mainly responsible for the development of trabecular bone mass in males ${ }^{30}$, in contrast to the important role of estrogens in females ${ }^{31}$. In this cohort, more girls progressed through the later stages of puberty than boys. Thus, it is likely that more girls were exposed to increased estrogen levels than boys were exposed to increased androgen levels. In girls, the associated estrogen surge may have also masked the small negative effect of corticosteroids and low vitamin D levels on bone health. Given the same chronological age, boys have a consistently lower biological age compared to girls ${ }^{32}$. This is reflected by the fact that boys achieve a peak bone mass later than girls. It is recognized that the growing skeleton is particularly susceptible to the adverse effects of corticosteroids ${ }^{24}$. Hence, it is possible that the delayed bone maturation pattern in boys predisposes them to increased adverse effects from corticosteroids and low vitamin D.

In addition to its direct effect on bone, low vitamin D levels may be associated with decreased BMA through increased OCS use in children with asthma. In the CAMP cohort, Brehm et al found that individuals with vitamin D insufficiency and receiving ICS had 1.7 times increased odds of severe asthma exacerbation over the 4 years of the trial, compared to those who were vitamin D sufficient and on ICS. This corroborates with their previous study of 616 Costa Rican children with asthma, where higher vitamin D levels were associated with a reduced odds of hospitalization ${ }^{15}$. Vitamin $\mathrm{D}$ insufficiency results in increased exacerbations, which in turn lead to increased OCS use, thus leading to further decrease in BMA. Together with our findings, this suggests that patients with frequent exacerbations may benefit from a vitamin D level assessment as these individuals are at greatest risk for decreased BMA.

Although CAMP included a higher proportion of minority subjects (13.3\% black, $9.4 \%$ Hispanic and $9.0 \%$ others $^{11}$ ) compared to other pediatric asthma trials, it was a predominantly white, non-disadvantaged cohort, therefore the generalizability of our findings need to be addressed. Children at risk for hypovitaminosis D, including those with a nonwhite ethnicity, who are obese, or in low socioeconomic status, may be even more susceptible to the adverse effects of steroids on bone health. Interestingly, a recent study described a significant decrease in BMD with decreasing vitamin D levels in whites and Mexican-Americans, but not among blacks ${ }^{33}$. Furthermore, in blacks, the inverse association between vitamin $\mathrm{D}$ and parathyroid hormone was observed only below the threshold of vitamin D deficiency (20 ng/mL), suggesting that African-Americans may require much lower vitamin D levels to experience the associated side effects. Further studies are 
warranted to examine the effects of vitamin D on bone health among individuals of different ethnic backgrounds.

The current study is limited by the fact that only one measure of serum vitamin D was used. Ideally, vitamin D measurements over time may allow for a more confident classification of whether an individual is vitamin D sufficient or insufficient and for the identification of seasonal variability in vitamin D levels. However, our results remained unchanged after adjusting for the season when vitamin D level was drawn (data not shown). In CAMP, a second vitamin D measurement was taken at the end of the study. The present study focused on the ability of vitamin D to modify the effects of corticosteroids on future BMA; therefore only the baseline level was used. Furthermore, using only subjects who had consistent levels at both time points (insufficient or sufficient at both times) significantly restricted our sample size. There was also potential for misclassification of subjects given that the measurements were not necessarily drawn during the same seasons. Nonetheless, using only individuals with consistent levels of vitamin $\mathrm{D}(\mathrm{n}=479)$, the interaction between the number of course of OCS and vitamin D on BMA remained significant $(\mathrm{p}=0.042)$. A large longitudinal, population-based study showed that despite seasonal variations in serum vitamin D, subjects with low serum vitamin D levels are unlikely to have substantial improvement 14 years later ${ }^{35}$. Hofmann et al also found a significant correlation between vitamin $D$ levels at baseline and 1 and 5 years ${ }^{36}$. Taken together, these findings support the use of a single vitamin D level measurement as predictor for future disease. Since bone health was not a primary outcome in CAMP, we did not have data on each subject's physical activity level or dietary changes. Although these variables are associated with BMA, diet is a limited source of vitamin $\mathrm{D}^{37}$ and overall physical activity is not associated with vitamin $\mathrm{D}$, therefore confounding, if present, is minimal. Physical activity outdoor may be a proxy for sun exposure, but to the extent that this would influence serum vitamin D status will be reflected in the serum levels that we have measured. Our study may have lacked power to detect some association, as CAMP was not designed to assess BMA. Although we found a significant association between ICS exposure and decreasing BMA in vitamin D sufficient boys ( $\mathrm{p}=0.007$ ), the interaction between vitamin $\mathrm{D}$ and ICS exposure was not significant $(\mathrm{p}=0.48)$. This observed association may be due to an outlier effect, although we may not have adequate power to detect a true effect modification by vitamin $\mathrm{D}$.

\section{Conclusion}

Our study demonstrates a dosage-dependent effect of intermittent oral corticosteroid use on bone mineral accretion in boys with asthma, which is significantly modified by baseline serum vitamin D levels. The findings of this study may have important clinical implications. Vitamin D insufficiency and asthma are two prevalent conditions in children. The use of oral corticosteroids is also a common occurrence among children with asthma. This study not only supports an adverse effect on bone mineral accretion associated with increasing use of OCS in boys, but also demonstrates that this negative effect is exacerbated by low serum vitamin $\mathrm{D}$. While further research is needed to confirm this finding, and whether vitamin $\mathrm{D}$ supplementation can confer clinical benefits on future bone health, our data suggests that children, in particular boys, with asthma who have frequent exacerbations requiring OCS treatment may benefit from a vitamin $\mathrm{D}$ assessment and that vitamin $\mathrm{D}$ supplementation in these children may help to preserve bone mineral density.

\section{Supplementary Material}

Refer to Web version on PubMed Central for supplementary material. 


\section{Acknowledgments}

The Childhood Asthma Management Program is supported by contracts NO1-HR-16044, 16045, 16046, 16047, $16048,16049,16050,16051$, and 16052 with the National Heart, Lung, and Blood Institute and General Clinical Research Center grants M01RR00051, M01RR0099718-24, M01RR02719-14, and RR00036 from the National Center for Research Resources. Additional support for this research came from grants P50 HL67664, T32 HL07427 and R21 HL089842 from the National Institutes of Health and the National Heart, Lung and Blood Institute.

\section{Abbreviations}

$\begin{array}{ll}\text { BMA } & \text { Bone mineral accretion } \\ \text { BMD } & \text { Bone mineral density } \\ \text { CAMP } & \text { Childhood Asthma Management Program } \\ \text { DEXA } & \text { Dual-energy radiograph absorptiometry } \\ \text { ICS } & \text { Inhaled corticosteroid } \\ \text { OCS } & \text { Oral corticosteroid } \\ \text { PTH } & \text { Parathyroid hormone }\end{array}$

\section{References}

1. Looker AC, Melton LJ 3rd, Harris TB, Borrud LG, Shepherd JA. Prevalence and trends in low femur bone density among older US adults: NHANES 2005-2006 compared with NHANES III. Journal of bone and mineral research : the official journal of the American Society for Bone and Mineral Research. 2010; 25:64-71. [PubMed: 19580459]

2. van der Sluis IM, de Ridder MA, Boot AM, Krenning EP, de Muinck Keizer-Schrama SM. Reference data for bone density and body composition measured with dual energy xray absorptiometry in white children and young adults. Archives of disease in childhood. 2002; 87:3417. discussion -7. [PubMed: 12244017]

3. Holick MF. Resurrection of vitamin D deficiency and rickets. The Journal of clinical investigation. 2006; 116:2062-72. [PubMed: 16886050]

4. Ginde AA, Mansbach JM, Camargo CA Jr. Association between serum 25-hydroxyvitamin D level and upper respiratory tract infection in the Third National Health and Nutrition Examination Survey. Archives of internal medicine. 2009; 169:384-90. [PubMed: 19237723]

5. Cranney A, Weiler HA, O'Donnell S, Puil L. Summary of evidence-based review on vitamin D efficacy and safety in relation to bone health. The American journal of clinical nutrition. 2008; 88:513S-9S. [PubMed: 18689393]

6. Canalis E, Mazziotti G, Giustina A, Bilezikian JP. Glucocorticoid-induced osteoporosis: pathophysiology and therapy. Osteoporosis international : a journal established as result of cooperation between the European Foundation for Osteoporosis and the National Osteoporosis Foundation of the USA. 2007; 18:1319-28. [PubMed: 17566815]

7. Brown JJ, Zacharin MR. Proposals for prevention and management of steroid-induced osteoporosis in children and adolescents. Journal of paediatrics and child health. 2005; 41:553-7. [PubMed: 16398835]

8. Lifetime asthma prevalence percents by age, United States: National Health Interview Survey. Center for Disease Control and Prevention; 2008. Available from http://www.cdc.gov/asthma/nhis/08/table2-1.htm

9. EPR-3. NIH Publication No 08-4051. Bethesda, MD: U.S. Department of Health and Human Services; National Institutes of Health; National Heart, Lung, and Blood Institute; National Asthma Education and Prevention Program; 2007. Expert Panel Report 3 (EPR3): Guidelines for the Diagnosis and Management of Asthma (EPR-3 2007).

10. Kelly HW, Van Natta ML, Covar RA, Tonascia J, Green RP, Strunk RC. Effect of long-term corticosteroid use on bone mineral density in children: a prospective longitudinal assessment in the 
childhood Asthma Management Program (CAMP) study. Pediatrics. 2008; 122:e53-61. [PubMed: 18595975]

11. The Childhood Asthma Management Program Research Group. Long-term effects of budesonide or nedocromil in children with asthma. The New England journal of medicine. 2000; 343:105463. [PubMed: 11027739]

12. Brehm JM, Schuemann B, Fuhlbrigge AL, Hollis BW, Strunk RC, Zeiger RS, et al. Serum vitamin D levels and severe asthma exacerbations in the Childhood Asthma Management Program study. The Journal of allergy and clinical immunology. 2010; 126:52-8. e5. [PubMed: 20538327]

13. Hollis BW, Kamerud JQ, Selvaag SR, Lorenz JD, Napoli JL. Determination of vitamin D status by radioimmunoassay with an 125I-labeled tracer. Clinical chemistry. 1993; 39:529-33. [PubMed: 8448871]

14. Holick MF. Vitamin D status: measurement, interpretation, and clinical application. Annals of epidemiology. 2009; 19:73-8. [PubMed: 18329892]

15. Brehm JM, Celedon JC, Soto-Quiros ME, Avila L, Hunninghake GM, Forno E, et al. Serum vitamin D levels and markers of severity of childhood asthma in Costa Rica. American journal of respiratory and critical care medicine. 2009; 179:765-71. [PubMed: 19179486]

16. Genant HK, Grampp S, Gluer CC, Faulkner KG, Jergas M, Engelke K, et al. Universal standardization for dual x-ray absorptiometry: patient and phantom cross-calibration results. Journal of bone and mineral research : the official journal of the American Society for Bone and Mineral Research. 1994; 9:1503-14. [PubMed: 7817795]

17. Turner S, Thomas M, von Ziegenweidt J, Price D. Prescribing trends in asthma: a longitudinal observational study. Archives of disease in childhood. 2009; 94:16-22. [PubMed: 18701558]

18. Roux C, Kolta S, Desfougeres JL, Minini P, Bidat E. Long-term safety of fluticasone propionate and nedocromil sodium on bone in children with asthma. Pediatrics. 2003; 111:e706-13. [PubMed: 12777589]

19. Bahceciler NN, Sezgin G, Nursoy MA, Barlan IB, Basaran MM. Inhaled corticosteroids and bone density of children with asthma. The Journal of asthma : official journal of the Association for the Care of Asthma. 2002; 39:151-7. [PubMed: 11990230]

20. Baraldi E, Bollini MC, De Marchi A, Zacchello F. Effect of beclomethasone dipropionate on bone mineral content assessed by X-ray densitometry in asthmatic children: a longitudinal evaluation. The European respiratory journal : official journal of the European Society for Clinical Respiratory Physiology. 1994; 7:710-4. [PubMed: 8005253]

21. Matsumoto H, Ishihara K, Hasegawa T, Umeda B, Niimi A, Hino M. Effects of inhaled corticosteroid and short courses of oral corticosteroids on bone mineral density in asthmatic patients : a 4-year longitudinal study. Chest. 2001; 120:1468-73. [PubMed: 11713121]

22. Rajasekaran K, Seth R, Abelson A, Batra PS. Prevalence of metabolic bone disease among chronic rhinosinusitis patients treated with oral glucocorticoids. American journal of rhinology \& allergy. 2010; 24:215-9. [PubMed: 20537290]

23. Bagger YZ, Tanko LB, Alexandersen P, Hansen HB, Qin G, Christiansen C. The long-term predictive value of bone mineral density measurements for fracture risk is independent of the site of measurement and the age at diagnosis: results from the Prospective Epidemiological Risk Factors study. Osteoporosis international : a journal established as result of cooperation between the European Foundation for Osteoporosis and the National Osteoporosis Foundation of the USA. 2006; 17:471-7. [PubMed: 16261280]

24. van Staa TP, Cooper C, Leufkens HG, Bishop N. Children and the risk of fractures caused by oral corticosteroids. Journal of bone and mineral research : the official journal of the American Society for Bone and Mineral Research. 2003; 18:913-8. [PubMed: 12733732]

25. Jia D, O'Brien CA, Stewart SA, Manolagas SC, Weinstein RS. Glucocorticoids act directly on osteoclasts to increase their life span and reduce bone density. Endocrinology. 2006; 147:5592-9. [PubMed: 16935844]

26. Huybers S, Naber TH, Bindels RJ, Hoenderop JG. Prednisolone-induced Ca2+ malabsorption is caused by diminished expression of the epithelial Ca2+ channel TRPV6. American journal of physiology Gastrointestinal and liver physiology. 2007; 292:G92-7. [PubMed: 16901990] 
27. Carnevale V, Nieddu L, Romagnoli E, Battista C, Mascia ML, Chiodini I, et al. Regulation of PTH secretion by 25 -hydroxyvitamin D and ionized calcium depends on vitamin D status: a study in a large cohort of healthy subjects. Bone. 2010; 47:626-30. [PubMed: 20601288]

28. Bischoff-Ferrari HA, Dietrich T, Orav EJ, Dawson-Hughes B. Positive association between 25hydroxy vitamin D levels and bone mineral density: a population-based study of younger and older adults. The American journal of medicine. 2004; 116:634-9. [PubMed: 15093761]

29. Wasilewska A, Rybi-Szuminska A, Zoch-Zwierz W. Serum RANKL, osteoprotegerin (OPG), and RANKL/OPG ratio in nephrotic children. Pediatric nephrology. 2010; 25:2067-75. [PubMed: 20602239]

30. Callewaert F, Venken K, Ophoff J, De Gendt K, Torcasio A, van Lenthe GH, et al. Differential regulation of bone and body composition in male mice with combined inactivation of androgen and estrogen receptor-alpha. The FASEB journal : official publication of the Federation of American Societies for Experimental Biology. 2009; 23:232-40.

31. Lindberg MK, Alatalo SL, Halleen JM, Mohan S, Gustafsson JA, Ohlsson C. Estrogen receptor specificity in the regulation of the skeleton in female mice. The Journal of endocrinology. 2001; 171:229-36. [PubMed: 11691642]

32. Baxter-Jones AD, Faulkner RA, Forwood MR, Mirwald RL, Bailey DA. Bone mineral accrual from 8 to 30 years of age: an estimation of peak bone mass. Journal of bone and mineral research : the official journal of the American Society for Bone and Mineral Research. 2011; 26:1729-39. [PubMed: 21520276]

33. Gutierrez OM, Farwell WR, Kermah D, Taylor EN. Racial differences in the relationship between vitamin D, bone mineral density, and parathyroid hormone in the National Health and Nutrition Examination Survey. Osteoporosis international : a journal established as result of cooperation between the European Foundation for Osteoporosis and the National Osteoporosis Foundation of the USA. 2011; 22:1745-53. [PubMed: 20848081]

34. Zemel BS, Kalkwarf HJ, Gilsanz V, Lappe JM, Oberfield S, Shepherd JA, et al. Revised reference curves for bone mineral content and areal bone mineral density according to age and sex for black and non-black children: results of the bone mineral density in childhood study. The Journal of clinical endocrinology and metabolism. 2011; 96:3160-9. [PubMed: 21917867]

35. Jorde R, Sneve M, Hutchinson M, Emaus N, Figenschau Y, Grimnes G. Tracking of serum 25hydroxyvitamin D levels during 14 years in a population-based study and during 12 months in an intervention study. American journal of epidemiology. 2010; 171:903-8. [PubMed: 20219763]

36. Hofmann JN, Yu K, Horst RL, Hayes RB, Purdue MP. Long-term variation in serum 25hydroxyvitamin D concentration among participants in the Prostate, Lung, Colorectal, and Ovarian Cancer Screening Trial. Cancer epidemiology, biomarkers \& prevention : a publication of the American Association for Cancer Research, cosponsored by the American Society of Preventive Oncology. 2010; 19:927-31.

37. O’Mahony L, Stepien M, Gibney MJ, Nugent AP, Brennan L. The potential role of vitamin D enhanced foods in improving vitamin D status. Nutrients. 2011; 3:1023-41. [PubMed: 22292109]

\section{CAMP Credit Roster}

\section{Source of funding}

The Childhood Asthma Management Program trial and CAMP Continuation Study were supported by contracts NO1-HR-16044, 16045, 16046, 16047, 16048, 16049, 16050, 16051, and 16052 with the National Heart, Lung, and Blood Institute and General Clinical Research Center grants M01RR00051, M01RR0099718-24, M01RR02719-14, and RR00036 from the National Center for Research Resources. The CAMP Continuation Study/Phases 2 and 3 were supported by grants U01HL075232, U01HL075407, U01HL075408, U01HL075409, U01HL075415, U01HL075416, U01HL075417, U01HL075419, U01HL075420, and U01HL075408 from the National Heart, Lung, and Blood Institute.

Members of the CAMP Research Group: 


\section{Clinical centers}

ASTHMA, Inc, Seattle, WA: Paul Williams, MD (Principal Investigator); Mary V. Lasley, MD (Co-Director); Tamara Chinn, MSN, ARNP (Coordinator). Michele Hinatsu, MSN, ARNP; Clifton T. Furukawa, MD; Leonard C. Altman, MD; Frank S. Virant, MD; Michael S. Kennedy, MD; Jonathan W. Becker, MD; Stephen Tilles, MD; Miranda MacLaren. C. Warren Bierman, MD (1992-1997); Dan Crawford, RN (1996-2002); Thomas DuHamel (1991-2004); Heather Eliassen, BA (1996-1999); Babi Hammond (1996-1999); Dominick A. Minotti, MD (1992-2003); Chris Reagan (1992-2003); Gail Shapiro (1991-2006, Principal Investigator); Marian Sharpe, RN (1992-1994); Ashley Tatum, MD (2004-2007); Grace White (1991-2007). Timothy G. Wighton, PhD (1994-1998).

Brigham \& Women's Hospital, Boston, MA: Anne Fuhlbrigge, MD (Principal Investigator); Anne Plunkett, NP, MS (Coordinator). Nancy Madden, RN, BSN; Mark Boehnert, MD; Christine Darcy; Anita Feins, MD; Natalia Kandror, MD; Kelly MacAulay, MD; Scott Weiss MD. Walter Torda, MD (Co-Investigator Director, 1993-2003); Martha Tata, RN (1993-2002); Sally Babigian, RN (1997-1999); Peter Barrant, MD (2004-2007); Linda Benson (1998-2004); Jose Caicedo (1998-1999); Tatum Calder (1998-2001); Anthony DeFilippo (1994-2000); Cindy Dorsainvil (1998-2001); Julie Erickson (19981999); Phoebe Fulton (1997); Mary Grace, RN (1994-1996); Jennifer Gilbert (1997-1998); Dirk Greineder, MD (1993-2000); Stephanie Haynes (1993-1998); Margaret Higham, MD (1996-1998); Deborah Jakubowski (1999); Susan Kelleher (1993-1997); Jay Koslof, PhD (1993-1995); Dana Mandel (1996-1998); Patricia Martin (2001-2003); Agnes Martinez (1994-1997); Jean McAuliffe (1994-1995); Erika Nakamoto (2002-2004); Paola Pacella (1993-1998); Paula Parks (1993-1995); Johanna Sagarin (1998-1999); Kay Seligsohn, PhD (1995-2004); Susan Swords (2003-2005); Meghan Syring (1998-2001); June Traylor, MSN, RN (1996-1998); Melissa Van Horn, PhD (1996-1999); Carolyn Wells, RN (19931995); Ann Whitman, RN (1994-1996).

The Hospital for Sick Children, Toronto, Ontario, Canada: Hartmut Grasemann, MD (Principal Investigator); Melody Miki, RN, BSN (Coordinator); Melinda Solomon, MD; Padmaja Subbarao, MD. Ian MacLusky, MD, FRCP (Director 1999-2007); Joe Reisman, MD, FRCP(C), MBA (Director, 1996-1999); Henry Levison, MD, FRCP(C) (Director, 1992-1996); Anita Hall, RN (Coordinator, 1993-2007). Yola Benedet (1994-1999); Susan Carpenter, RN (1998-2001); Jennifer Chay (2004); Michelle Collinson, RN (1994-1998); Jane Finlayson-Kulchin, RN (1994-1998); Kenneth Gore, MA (1993-1999); Nina Hipolito, RN (2003-2004); Noreen Holmes, RRT (1998-1999); Erica Hoorntje, RN (2002-2003); Sharon Klassen, MA(1999-2000); Joseé Quenneville, MSc (1993-1995); Renée Sananes, PhD (1993-2004); Christine Wasson, PhD (1999); Margaret Wilson, RN (2001-2002).

Johns Hopkins Asthma \& Allergy Center, Baltimore, MD: N. Franklin Adkinson, Jr, MD (Director); Deborah Bull, LPN (Coordinator); Stephanie Philips, RN. Peyton Eggleston, MD (Co-Director, 1991-2004); Karen Huss, DNSc (Co-Investigator, 1991-2004); Leslie Plotnick, MD (Co-Investigator, 1991-1999); Margaret Pulsifer, PhD (Co-Investigator, 1993--2004); Cynthia Rand, PhD (Co-Investigator, 1991-2004). Elizabeth Aylward, PhD (1991-2004), Nancy Bollers, RN (Coordinator, 1993-2004); Kathy Pessaro (2004-2007); Barbara Wheeler, RN, BSN (Coordinator, 1991-1999).

National Jewish Health, Denver, CO: Stanley Szefler, MD (Director); Harold S. Nelson, MD (Co-Director); Bruce Bender, PhD (Co-Investigator); Ronina Covar, MD (CoInvestigator); Andrew Liu, MD (Co-Investigator); Joseph Spahn, MD (Co-Investigator); D Sundström (Coordinator); Melanie Phillips; Michael P. White; Melanie Gleason, PA-C; Marzena Krawiec, MD; Gary Larsen, MD; Gayle Spears, PA-C. Kristin Brelsford (1997- 
1999); Jessyca Bridges (1995-1997); Jody Ciacco (1993-1996); Michael Eltz (1994-1995); Jeryl Feeley, MA (Coordinator, 1992-1995); Michael Flynn (1995-1996); Tara JunkBlanchard (1997-2000); Joseph Hassell (1992-1998); Marcia Hefner (1992-1994); Caroline Hendrickson, RN (1995-1998; Coordinator, 1995-1997); Daniel Hettleman, MA (19951996); Charles G. Irvin, PhD (1992-1998); Alan Kamada, PharmD (1994-1997); Sai Nimmagadda, MD (1993-1996); Kendra Sandoval (1995-1997); Jessica Sheridan (19941995); Trella Washington (1993-1997); Eric Willcutt, MA (1996-1997). We also thank the pediatric allergy/immunology and pulmonary fellows for their participation (Ivan Cardona, MD; Kirstin Carel, MD; Jayna Doshi, MD; Rich Hendershot, MD; Jeffrey Jacobs, MD; Neal Jain, MD; June-ku Brian Kang, MD; Tracy Kruzick, MD; Harvey Leo, MD; Beth Macomber, MD; Jonathan Malka, MD; Chris Mjaanes, MD; John Prpich, MD; Lora Stewart, MD; Ben Song, MD; Grace Tamesis, MD).

University of California, San Diego and Kaiser Permanente Southern California Region, San Diego, CA: Robert S. Zeiger, MD, PhD (Director); Noah Friedman, MD (CoInvestigator); Michael H. Mellon, MD (Co-Investigator); Michael Schatz, MD (CoInvestigator); Kathleen Harden, RN (Coordinator). Terrie Long, RN; Travis Macaraeg; Elsa Rodriguez; Eva Rodriguez, RRT. Sandra Christensen, MD (2004-2007); James G. Easton, MD (Co-Director, 1993-1994); M. Feinberg (1997-1998); Linda L. Galbreath (1991-2002); Jennifer Gulczynski (1998-1999); Ellen Hansen (1995-1997); Al Jalowayski, PhD (CoInvestigator, 1991-2005); Elaine Jenson (2004-2007); Alan Lincoln, $\mathrm{PhD}$ (Co-Investigator, 1991-2003); Jennie Kaufman (1994); Shirley King, MSW (1992-1999); Brian Lopez (1997-1998); Michaela Magiari-Ene, MA (1994-1998); Kathleen Mostafa, RN (19941995); Avraham Moscona (1994-1996); Catherine A. Nelle, RN (1991-2005); Jennifer Powers (2001-2003); Karen Sandoval (1995-1996); Nevin W. Wilson, MD (Co-Director, 1991-1993).

University of New Mexico, Albuquerque, NM: H. William Kelly, PharmD (Director); Aaron Jacobs (Co-Investigator); Hengameh H. Raissy, PharmD, PhC (Co-Investigator); Mary Spicher, RN (Coordinator). Christina Batson. Robert Annett, $\mathrm{PhD}$ (Co-Investigator, 1993-2004); Teresa Archibeque (1994-1999); Naim Bashir, MD (Co-Investigator, 19982005); H. Selda Bereket (1995-1998); Marisa Braun (1996-1999); Carrie Bush (19951999); Shannon C. Bush (2002-2007); Michael Clayton, MD (Co-Investigator, 1999-2001); Angel Colon-Semidey, MD (Co-Investigator, 1997-2000); Sara Devault (1993-1997); Anna Esparham (2004-2007); Roni Grad, MD (Co-Investigator, 1993-1995); David Hunt, RRT (1995-2004); Jeanne Larsson, RN (1995-1996); Katie McCallum (2009); Sandra McClelland, RN (Coordinator, 1993-1995); Bennie McWilliams, MD (Co-Investigator, Director, 1992-1998); Elisha Montoya (1997-2000); Margaret Moreshead (1996-1999); Shirley Murphy, MD (Co-Investigator, 1992-1994); Barbara Ortega, RRT (1993-1999); David Weers (1997-1998); Jose Zayas (1995-1996).

Washington University, St. Louis, MO: Robert C. Strunk, MD (Director); Leonard Bacharier, MD (Co-Investigator); Gordon R. Bloomberg, MD (Co-Investigator); Denise Rodgers, RPFT (Coordinator). Ellen Albers (1999-2003); James M. Corry, MD (CoInvestigator, 1995-2004); Karen DeMuth (2006-2007); Lila Kertz, MSN, RN, CPNP (2005-2007); Valerie Morgan, RRT (2004-2007); Cynthia Moseid (2007); Tina OliverWelker, CRTT (1993-2007); Deborah K. White, RPFT, RRT (1993-2007).

\section{Resource centers}

Data Coordinating Center, The Johns Hopkins University, Baltimore, MD: James Tonascia, PhD (Director). Patricia Belt; Karen Collins; Betty Collison; Ryan Colvin, MPH; John Dodge; Michele Donithan, MHS; Cathleen Ewing; Rosetta Jackson; Hope Livingston; 
Jill Meinert; Girlie Reyes; Michael Smith; Alice L. Sternberg, ScM; Mark L. Van Natta, MHS; Annette Wagoner; Laura Wilson, ScM; Robert Wise, MD; Katherine Yates, ScM.

Project Office, National Heart, Lung, and Blood Institute, Bethesda, MD: Virginia Taggart, MPH (Project Officer); Lois Eggers; James Kiley, PhD; Howard Moore; Gang Zheng, PhD. Paul Albert, PhD (1991-1999); Suzanne Hurd, PhD (1991-1999); Sydney Parker, PhD (1991-1994); Pamela Randall (1992-2003); Margaret Wu, PhD (1991-2001).

\section{Committees}

Data and Safety Monitoring Board: Michelle Cloutier, MD (Chair); John Connett, PhD; Leona Cuttler, MD; Frank Gilliland, MD, PhD. Clarence E. Davis, PhD (1993-2003); Howard Eigen, MD (1993-2009, Chair); David Evans, PhD (1993-2007); Meyer Kattan, MD (1993-2007); Rogelio Menendez, MD (1993-2007); F. Estelle R. Simons, MD (19932007); Sanford Leikin, MD (1993-1999).

Steering Committee: Robert Strunk, MD (Study Chair); N. Franklin Adkinson, MD; Robert Annett, PhD (1992-1995, 1997-1999); Bruce Bender, PhD; Mary Caesar, MHS (19941996); Reuben Cherniack, MD (Study Chair 1993-2007); Thomas R. DuHamel, PhD (1992-1994, 1996-1999); Anne Fuhlbrigge, MD; Hartmut Grasemann, MD; H. William Kelly, PharmD; Henry Levison, MD (1992-1996); Alan Lincoln, PhD (1994-1995); Ian MacLusky, MD (1999-2006); Bennie McWilliams, MD (1992-1998); Curtis L. Meinert, PhD; Sydney Parker, PhD (1991-1994); Joe Reisman, MD, FRCP(C), MBA (1991-1999); Denise Rodgers; Kay Seligsohn, PhD (1996-1997); Gail G. Shapiro, MD (1991-2006); Marian Sharpe (1993-1994); D Sundström (1998-1999); Stanley Szefler, MD; Virginia Taggart, MPH; Martha Tata, RN (1996-1998); James Tonascia, PhD; Scott Weiss, MD, MS; Barbara Wheeler, RN, BSN (1993-1994); Paul Williams, MD; Robert Wise, MD; Robert Zeiger, MD, PhD. 


\section{Clinical Implications}

Corticosteroid use in asthma is associated with a reduction in BMA. Vitamin D insufficiency is also associated with decreased BMD. However, the interaction between vitamin $\mathrm{D}$ and corticosteroids in asthma is not well understood. 


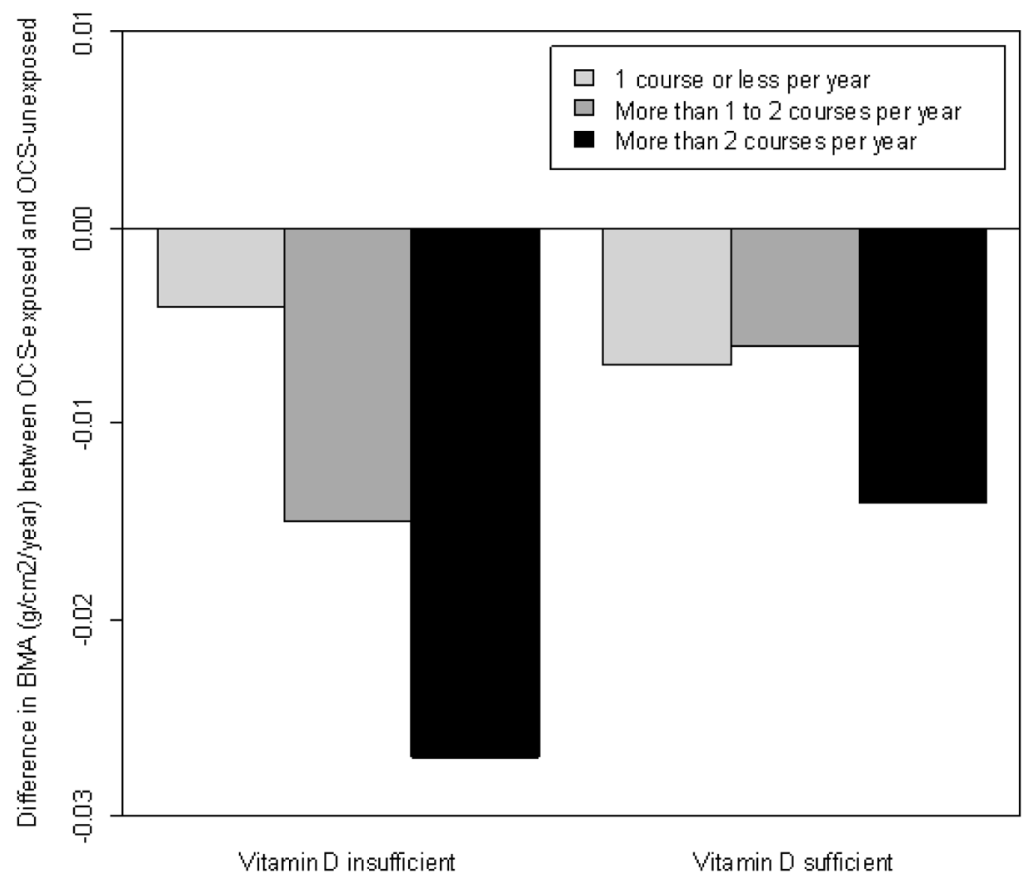

Figure 1.

Difference in BMA between OCS-exposed and OCS-unexposed in boys, by category of OCS exposure and vitamin D sufficiency status. Vitamin D insufficient boys who were exposed to more than 2 OCS courses per year had twice the difference in BMA compared to the vitamin D sufficient boys. 
Table I

Baseline characteristics

\begin{tabular}{|c|c|c|c|c|}
\hline \multicolumn{5}{|l|}{ Baseline characteristics $(n=780)$} \\
\hline & \multicolumn{2}{|c|}{ Vitamin D $\leq 30 \mathrm{ng} / \mathrm{ml}$} & \multicolumn{2}{|c|}{ Vitamin $D>30 \mathrm{ng} / \mathrm{ml}$} \\
\hline $\mathbf{N}(\%)$ & \multicolumn{2}{|l|}{$289(37.0)$} & \multicolumn{2}{|l|}{$491(63.0)$} \\
\hline Male (\%) & \multicolumn{2}{|l|}{$176(60.9)$} & \multicolumn{2}{|l|}{$306(62.3)$} \\
\hline Age, mean (SD), years & \multicolumn{2}{|l|}{$9.2(2.1)$} & \multicolumn{2}{|l|}{$8.8(2.1)$} \\
\hline Height, mean (SD), cm & \multicolumn{2}{|l|}{$135.6(13.9)$} & \multicolumn{2}{|c|}{$132.9(13.5)$} \\
\hline BMI percentile, median (IQR), kg/m² & \multicolumn{2}{|c|}{$76.9(49.0,93.1)$} & \multicolumn{2}{|c|}{$68.0(42.9,88.9)$} \\
\hline \multicolumn{5}{|l|}{ BMD, median (IQR), g/cm² } \\
\hline Baseline & \multicolumn{2}{|c|}{$0.64(0.59,0.72)$} & \multicolumn{2}{|c|}{$0.63(0.57,0.69)$} \\
\hline Vitamin D, median (IQR), ng/ml & \multicolumn{2}{|c|}{$24.0(19.6,27.5)$} & \multicolumn{2}{|c|}{$41.9(35.2,52.5)$} \\
\hline Exposure to passive smoking, $n(\%)$ & \multicolumn{2}{|l|}{$60(20.8)$} & \multicolumn{2}{|l|}{$130(26.4)$} \\
\hline \multicolumn{5}{|l|}{ Race/Ethnicity, n (\%) } \\
\hline White & \multicolumn{2}{|l|}{$158(54.7)$} & \multicolumn{2}{|l|}{$380(77.4)$} \\
\hline Black & \multicolumn{2}{|l|}{$71(24.6)$} & \multicolumn{2}{|l|}{$28(5.7)$} \\
\hline Hispanic & \multicolumn{2}{|l|}{$26(9.0)$} & \multicolumn{2}{|l|}{$46(9.4)$} \\
\hline Other & \multicolumn{2}{|l|}{$34(11.8)$} & \multicolumn{2}{|l|}{$37(7.5)$} \\
\hline \multicolumn{5}{|l|}{ Tanner stage, n (\% within sex) } \\
\hline Baseline & Male & Female & Male & Female \\
\hline Stage 1 & $117(67.2)$ & $81(71.6)$ & $220(72.6)$ & $131(70.8)$ \\
\hline Stage 2 & $40(23.0)$ & $14(12.4)$ & $69(22.8)$ & $37(20.0)$ \\
\hline Stage 3 & $13(7.5)$ & $9(8.0)$ & $9(3.0)$ & $12(6.5)$ \\
\hline Stage 4 & $4(2.3)$ & $7(6.2)$ & $5(1.6)$ & $4(2.2)$ \\
\hline Stage 5 & $0(0)$ & $2(1.8)$ & $0(0)$ & $1(0.5)$ \\
\hline \multicolumn{5}{|l|}{ At 4 years follow-up } \\
\hline Stage 1 & $29(16.7)$ & $8(7.3)$ & $86(28.5)$ & $18(9.9)$ \\
\hline Stage 2 & $46(26.4)$ & $26(23.9)$ & $72(23.8)$ & $41(22.5)$ \\
\hline Stage 3 & $25(14.4)$ & $25(23.0)$ & $37(12.3)$ & $43(23.6)$ \\
\hline Stage 4 & $31(17.8)$ & $20(18.3)$ & $38(12.6)$ & 34 (18.7) \\
\hline Stage 5 & $43(24.7)$ & $30(27.5)$ & $69(22.8)$ & $46(25.3)$ \\
\hline
\end{tabular}




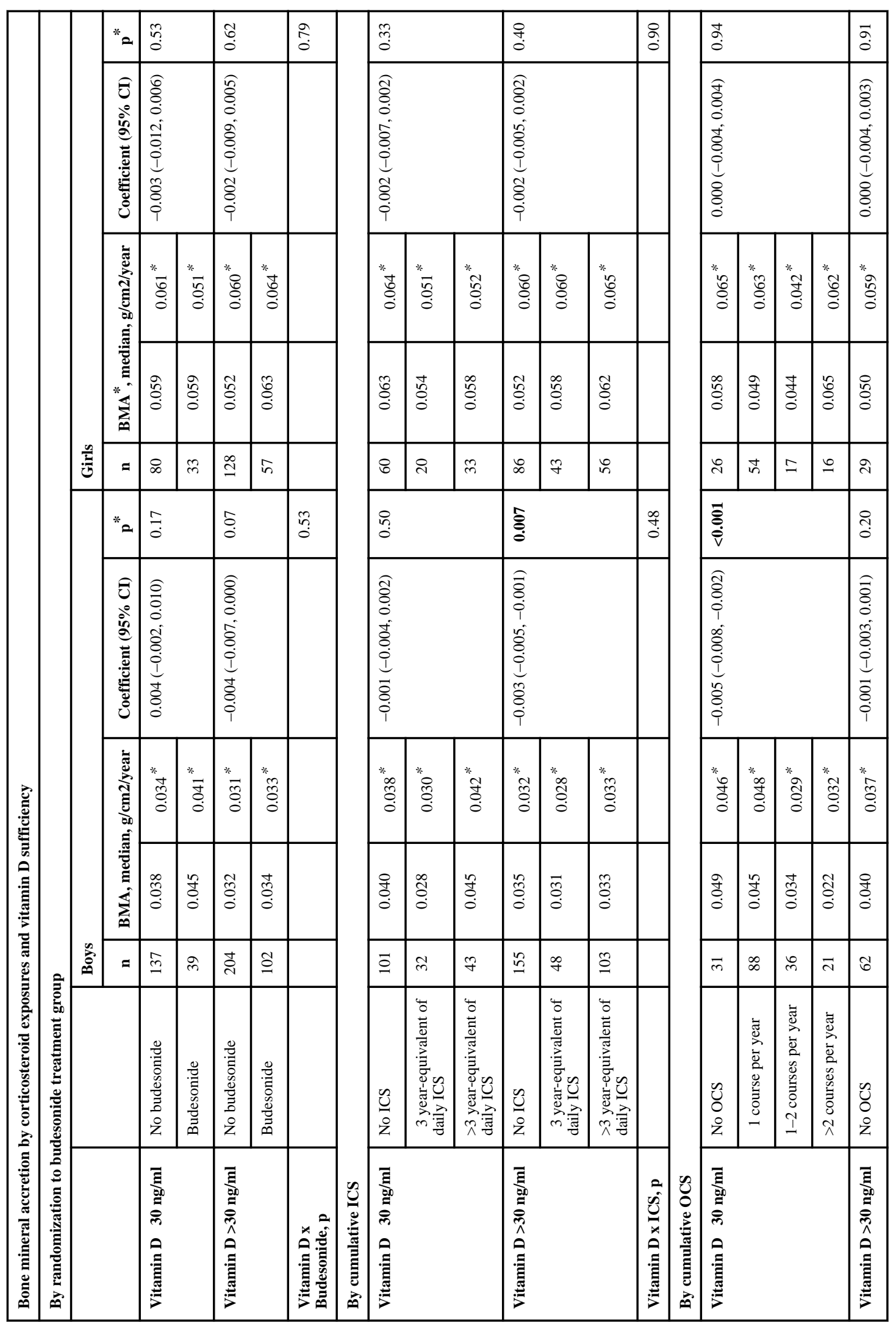




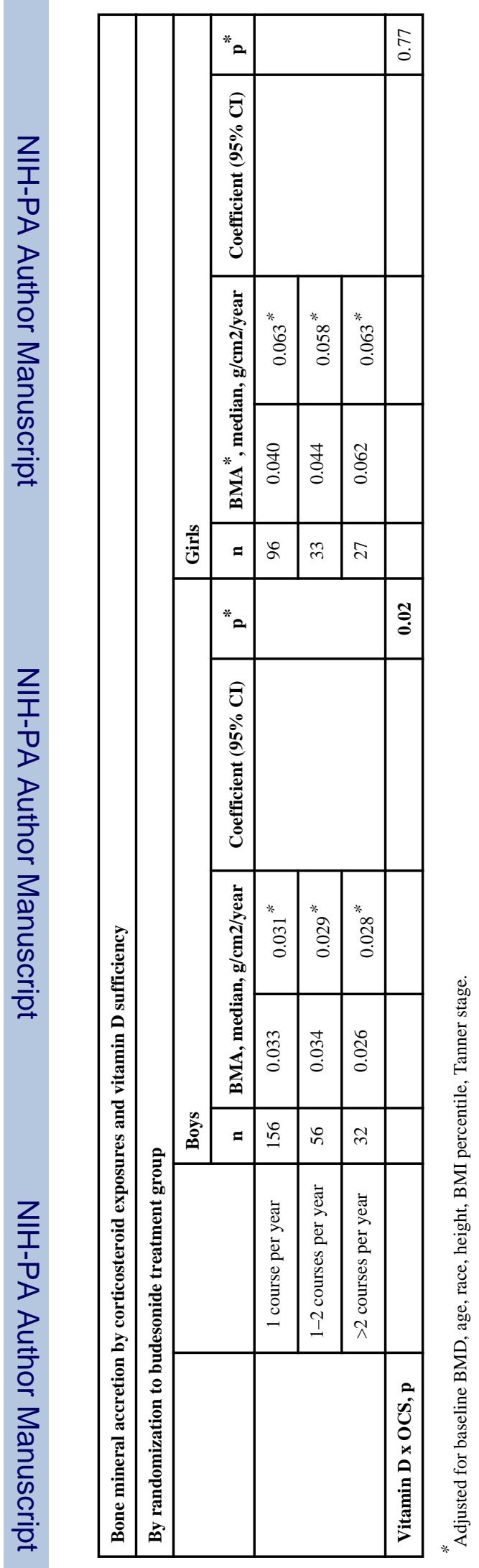

J Allergy Clin Immunol. Author manuscript; available in PMC 2013 July 01. 


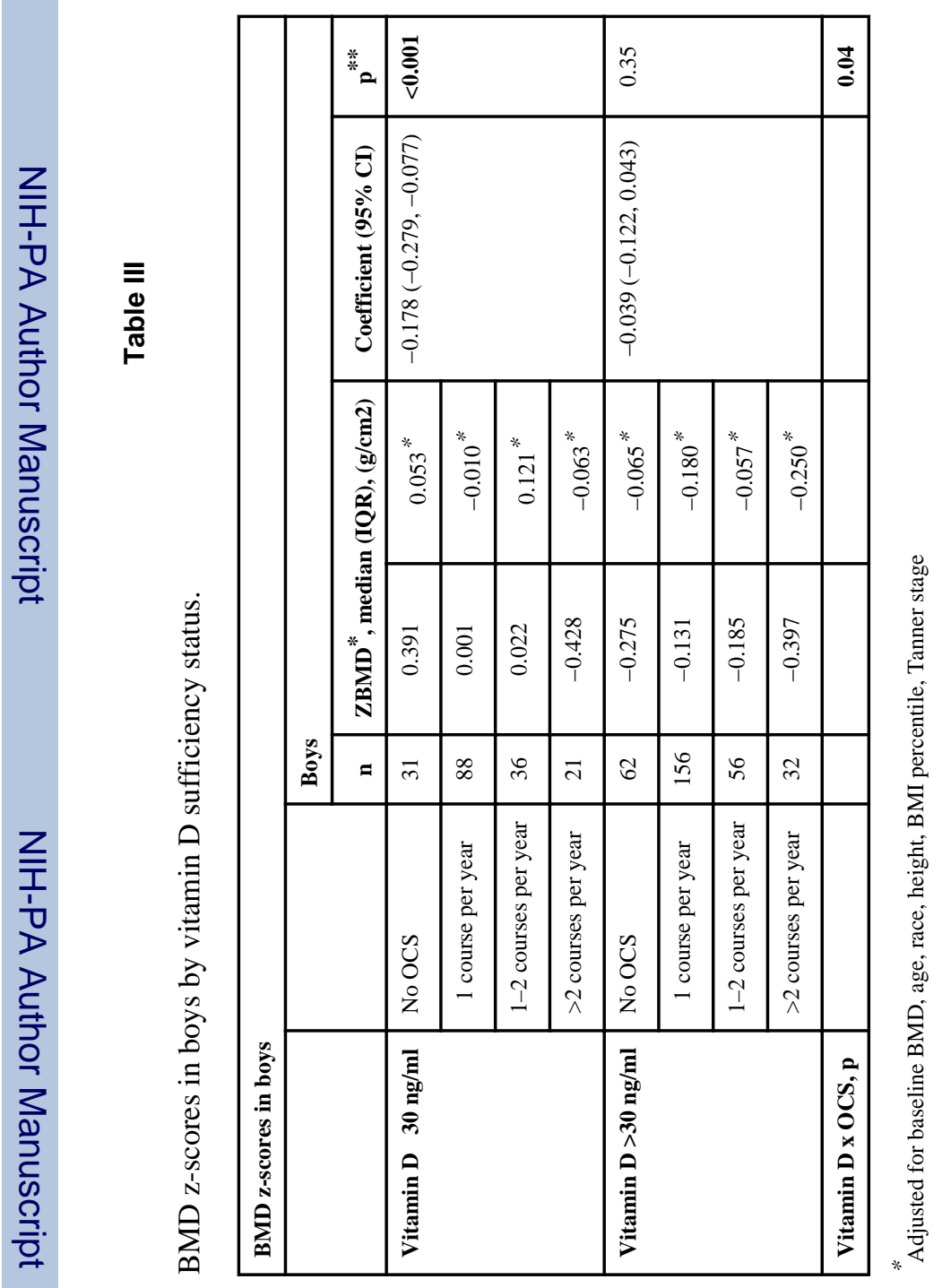

J Allergy Clin Immunol. Author manuscript; available in PMC 2013 July 01. 